REVISTA PREVENGÃ̃O DE INFECCÃO E SAÚDE

(REPIS)

\title{
Microbiological analysis of drinking taps of a public university in the state of Piauí
}

\author{
Análise microbiológica das torneiras dos bebedouros de uma universidade pública do estado do Piauí
}

Análisis microbiológico de los grifos de los bebederos de una universidad pública del estado de Piauí

Anderson de Melo Moreira ${ }^{1}$, Willden John Lopes de Aguiar ${ }^{1}$, Olavo Dionisio da Silva Dias ${ }^{1}$, Tiago Medeiros da Silva1, Amanda de Oliveira Sousa Cardoso ${ }^{1}$, Letícia Batista dos Santos ${ }^{1}$, Daniela Reis Joaquim de Freitas ${ }^{2}$

1. Universidade Federal do Piauí, Departamento de Enfermagem, Teresina-PI, Brasil.

2. Universidade Federal do Piauí, Centro de Ciências da Saúde, Departamento de parasitologia e microbiologia, Teresina-PI, Brasil.

\section{ABSTRACT}

Objectives: to carry out the microbiological analysis of drinking taps at a public university in the city of Teresina, Piauí. Methodology: Samples were collected from the faucets of 59 water fountains, inside the campus. Results: The results showed that all drinking water analyzed showed microbial growth, except one. Microorganisms such as Candida sp, Escherichia coli, Salmonella, Shigella, Staphylococcus (including S. aureus) and other enterobacteria were found. In order to verify the antimicrobial activity of S. aureus isolated populations, 5 different antimicrobial types were used, which showed $98 \%$ vancomycin resistance and $100 \%$ oxacillin resistance. Conclusion: microorganisms found as biofilms in taps are potentially pathogenic, especially S. aureus, which is heavily involved in community and hospital infections. The pattern of antimicrobial resistance found in isolated populations requires further studies and control measures to avoid its propagation.

Descriptors: Drinkers; Biofilm; Antimicrobial resistance.

\section{RESUMO}

Objetivos: realizar a análise microbiológica das torneiras dos bebedouros de uma universidade pública na cidade de Teresina, Piauí. Metodologia: As amostras foram coletadas das torneiras de 59 bebedouros, dentro do campus. Resultados: Os resultados mostraram que todos os bebedouros analisados apresentaram crescimento microbiano, exceto um. Foram encontrados micro-organismos como Candida sp, Escherichia coli, bactérias do gênero Salmonella, Shigella, Staphylococcus (incluindo a espécie S. aureus) e outras enterobactérias. Para verificar a atividade antimicrobiana das populações isoladas de $\mathrm{S}$. aureus foram utilizados 5 tipos de antimicrobianos diferentes, o que mostrou haver $98 \%$ de resistência à vancomicina e $100 \%$ de resistência à oxacilina. Conclusão: os micro-organismos encontrados como biofilme nas torneiras são potencialmente patogênicos, em especial S. aureus, que está bastante envolvido em infeccões comunitárias e hospitalares. 0 padrão de resistência antimicrobiana encontrada nas populações isoladas requer maiores estudos e medidas de controle para evitar sua propagação.

Descritores: Bebedouros; Biofilme; Resistência antimicrobiana.

\section{RESUMÉN}

Objetivos: realizar el análisis microbiológico de los grifos de los bebederos de una universidad pública en la ciudad de Teresina, Piauí. Metodología: Las muestras fueron recolectadas de los grifos de 59 bebederos, dentro del campus. Resultados: Los resultados mostraron que todos los bebederos analizados presentaron crecimiento microbiano, excepto uno. Se encontraron microorganismos como Candida sp, Escherichia coli, bacterias del género Salmonella, Shigella, Staphylococcus (incluyendo la especie S. aureus) y otras enterobacterias. Para verificar la actividad antimicrobiana de las poblaciones aisladas de $S$. aureus se utilizaron 5 tipos de antimicrobianos diferentes, lo que mostró que el $98 \%$ de resistencia a la vancomicina y el $100 \%$ de resistencia a la oxacilina. Conclusión: los microorganismos encontrados como biofilm en los grifos son potencialmente patógenos, en particular S. aureus, que está bastante involucrado en infecciones comunitarias y hospitalarias. El patrón de resistencia antimicrobiana encontrada en las poblaciones aisladas requiere mayores estudios y medidas de control para evitar su propagación.

Descriptores: Bebedores; Biofilm; Resistencia antimicrobiana.

\section{Como citar este artigo:}

Moreira AM, Aguiar WJL, Dias ODS, Silva TM, Cardoso AOS, Santos LB et al. Microbiological analysis of drinking taps of a public university in the state of Piauí. Rev Pre Infec e Saúde [Internet]. 2017;3(1):8-15. Available from: http://www.ojs.ufpi.br/index.php/nupcis/article/view/6243 


\section{INTRODUCTION}

Water is an essential chemical substance that is part of the structure and metabolism of all living things. It is present in approximately two-thirds of the planet's surface, and can be found in the form of rivers, lakes, seas, oceans, and glaciers. Of all the water on the surface of the planet, $98 \%$ is salty and the other $0,002 \%$ is freshwater, where only $2 \%$ is considered to be drinkable ${ }^{1}$.

The human being uses water in different ways, for example, in personal or household hygiene, preparation of meals, agricultural production, energy production and also for ingestion ${ }^{2}$. In order for it to be ingested, it must be considered potable and must undergo physical-chemical processes that eliminate solid impurities and microorganisms, since if the water is not treated properly, it can become a transmission vehicle of pathogens and substances toxic to the body.

Ordinance No. 2914/2011 of the Ministry of Health determines the norms and standards of water potability that must be ensured by the water supply companies ${ }^{3}$. The water intended for human consumption should be absent from total and thermotolerant coliforms (in $100 \mathrm{~mL}$ samples), which has the bacterium Escherichia coli as the main representative and which is present exclusively in the intestinal tract of homeothermic animals, which also includes the human being, in a way that does not pose a risk to consumers ${ }^{4}$.

In the state of Piauí, the processes of abstraction, treatment and distribution of water are made by the Water and Sewage Company of the State of Piauí - AGESPISA, which has the Parnaíba River as its main supplier of raw material. In the capital Teresina, the stretch traveled by the river is close to culverts and sewage pipes that discharge waste in it. For this and other reasons it is necessary the frequent monitoring and analysis of water quality and potability ${ }^{5}$.

In addition to the presence of microorganisms found in free-living form, there are those that have the ability to form clusters on different types of moist surfaces and share nutrients with each other. These aggregates are known as biofilms, which secrete extracellular polymer matrix substances in order to enhance the attachment of a cell to the surface, present multiple layers and be formed by different types of microorganisms. This type of training represents a functional and coordinated community development action in order to increase the survival rate ${ }^{6}$.

The formation of biofilms is very common on surfaces that are in constant humidity, for example, in the walls of swimming pools, water reservoirs, pipes, drinking fountains, etc. These conglomerates are more resistant to common disinfection methods and to antibiotics when compared to their effects on free microorganisms ${ }^{7}$. It is believed that about $65 \%$ of bacterial infections in humans come from the formation of biofilms.

The water available to the academic community of the University where the research takes place is redistributed and stored in reservoirs to be consumed in six centers and other areas redistributed within the Campus, and most of the students use it mainly for ingestion through the drinking fountains scattered throughout the entire university.

Because it is a place with an intense flow of people, these drinking fountains must be cleaned, monitored and replaced every six months, and the records of the operation must be shown when there is a resquest, since untreated water and the accumulation of organic matter and microorganisms in drinking 
fountains and pipes themselves become a means of propagation of pathogens.

From this perspective, the main objective of the present study was to analyze the quality of the water provided in the drinking fountains of a public university in Piauí, through the qualitative evaluation of microbiological tests.

\section{METHODS}

The study was carried out in the Campus of a public University of Piauí (UFPI) located in the eastern part of the capital of Piauí, Teresina. The Campus chosen is considered the seat unit from the other campuses present in the state where the teaching, research and extension are developed in six academic units: Center for Agricultural Sciences - CAS; Center of Educational Sciences - CES; Center for Human Sciences and Letters - CHSL, Center for Natural Sciences - CNS; Center for Health Sciences CHS and Technology Center -TC.

The collections were carried out between May and June 2017, where samples were collected from a total of 59 drinking fountains from the Campus. The distribution and organization took place according to the departments, rooms and reference points present in each center and also in the adjacent areas, which include the University Restaurants (UR), the Central Directory of Students (CDS), the Community Library and the Center of Natural Sciences 2 (CNS2).

For collection, sterile wooden rod swabs were used which were used to collect inside the drinking taps that had previously drained water for 1 minute, and then the material was filled into sterile $15 \mathrm{ml}$ conical plastic tubes previously identified in the tube and protocol of the research, to be packed in shelves and placed in styrofoam in order to maintain the ambient temperature $\left(36-37^{\circ} \mathrm{C}\right)$ and transported within a maximum time of 1 hour after the collection to the Nucleus Laboratory of Studies in Microbiology and Parasitology of the Department of Parasitology and Microbiology of the UFPI. Drinking fountains found disconnected had no samples collected. All the steps of collection, packaging and transportation took place according to the protocols in force in the Practical Manual of water analysis ${ }^{9}$ produced by the National Health Foundation (FUNASA).

All samples were placed in test tubes with $1 \mathrm{~mL}$ of sterile saline solution $(0.9 \% \mathrm{NaCl}$ in distilled water) $+2 \mathrm{~mL}$ of soybean casein and taken to the greenhouse for 18-24 hours growth at $37^{\circ} \mathrm{C}$. After growth, $200 \mu \mathrm{L}$ of the inoculums were pipetted into Petri dishes with Müller Hinton agar medium, spread with sterile Drigalski loops and brought to the greenhouse for colony growth of fungi and bacteria again for 18-24 hours $^{10}$.

Graph 01 - Quantity (\%) of samples obtained according to the academic unitys of the university.

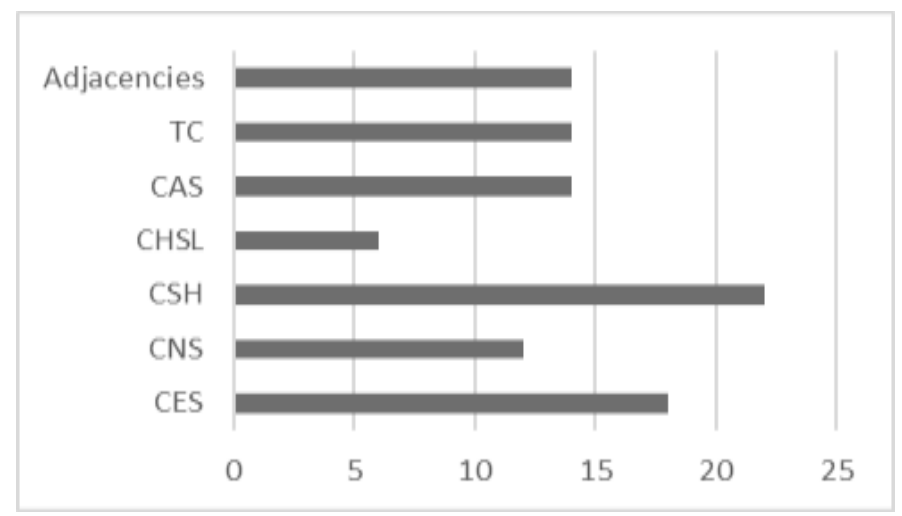

Note: Center for Agricultural Sciences - CAS; Center of Educational Sciences - CES; Center for Human Sciences and Letters - CHSL, Center for Natural Sciences - CNS; Center for Health Sciences - CHS and Technology Center -TC.

The raised colonies were differentiated by the different morphologies presented and seeded in sterile test tubes with $1 \mathrm{~mL}$ of saline solution and $2 \mathrm{~mL}$ of soybean casein broth and placed again for growth at $37^{\circ} \mathrm{C}$ for 18-24 hours. The cultured cultures were seeded (100 
$\mu \mathrm{l}$ in different solid culture mediums (Salmonella-Shigella, Salty Mannitol, Hektoen, Simmons Citrate, Brilliant Green, Sabouraud, McConkey and Bile esculin agar). The colonies that showed positivity in mannitol agar, later cultured in $\mathrm{BHI}$, were analyzed for colony morphology by Gram staining, and those samples that actually had morphology corresponding to $S$. aureus were submitted to confirmatory tests of catalase (hydrogen peroxide), Gram stain and coagulase test (Laborclin, Vargem Grande, Pinhais, Paraná).

With the confirmation of the identification of $\mathrm{S}$. aureus antibiotic tests were performed with paper discs of antibiotics, such as: Nalidixic Acid (NAL, $30 \mathrm{mcg}$ ), Amoxiline + Clavulanic Acid (30 m cg), Azithromycin (15 $\mathrm{mcg}$ ), Vancomycin $30 \mathrm{mcg}$ ) and Oxacillin (1 $\mathrm{mcg})$. The test was also carried out with the ATCC (American Type Culture Collection) ${ }^{\circledR}$ 25923 - S. aureus strain as a positive control sample (owned by the Research Laboratory in Microbiology of the Federal University of Piauí), since it has standards of references to sensitivity to known antibiotics.

\section{RESULTS AND DISCUSSION}

The 59 samples were ordered according to the centers, as can be seen in Table 1. However, the quantity of samples refers to the number of drinking fountains used for the collection. After the beginning of the microbial cultivation in Müller Hinton agar and colonies distinction by morphology, a total of 82 cultured colonies.

The results showed different microorganisms (Table 1) present in all drinking fountains analyzed, with the exception of a single device located in the Biophysics Department, within the CCS: this one did not present microbial growth, resulting in microbial growth in $98 \%$ of drinking fountains.
Table 1: Distribution of the quantity of samples obtained in each center, in the university researched.

\begin{tabular}{lc}
\hline Centers & $\begin{array}{c}\text { Number of } \\
\text { samples }\end{array}$ \\
\hline CCS & 13 \\
CCN & 7 \\
CCE & 11 \\
CCHL & 4 \\
CT & 8 \\
CCA & 8 \\
Adjacencies & 8 \\
\hline TOTAL & 59 \\
\hline
\end{tabular}

Note: Center for Agricultural Sciences - CAS; Center of Educational Sciences - CES; Center for Human Sciences and Letters - CHSL, Center for Natural Sciences - CNS; Center for Health Sciences - CHS and Technology Center -TC.

The results showed different microorganisms (Table 1) present in all drinking fountains analyzed, with the exception of a single device located in the Biophysics Department, within the CCS: this one did not present microbial growth, resulting in microbial growth in $98 \%$ of drinking fountains.

Among the microorganisms identified, it was possible to find Candida $s p$, which had growth of $96.25 \%$ among the colonies grown in Sabouraud medium, and the remaining 3.75\% did not grow. The genus Candida is common among the human microbiota, and its presence in water is not a real danger to public health, except in cases where there is variation in the individual's immune system, since it's infections are considered opportunistic ${ }^{11}$.

There was also growth of bacteria of the genera Salmonella and Shigella, which had growth of $18.75 \%$ among the colonies grown in Samonella-Shigella medium. The genus Salmonella has two species: Salmonella enterica and Salmonella bongori, and is part of the Enterobacteriaceae family, commonly known as enterobacteria, which are characterized by being short and gram 
negative rods ${ }^{12}$. Other enterobacteria, such as Escherichia coli.

Colonies of bacteria of the genus Staphylococcus were found, which are abundantly distributed both on the body surface of humans and other animals, in water, soil, plants and objects. Chart 1 shows the main pathogens found and the main diseases caused by them.

Chart 1 - Quantity (in absolute number and\%) of drinking taps samples from university with presence of pathogens present and the main characteristic of infection caused by them.

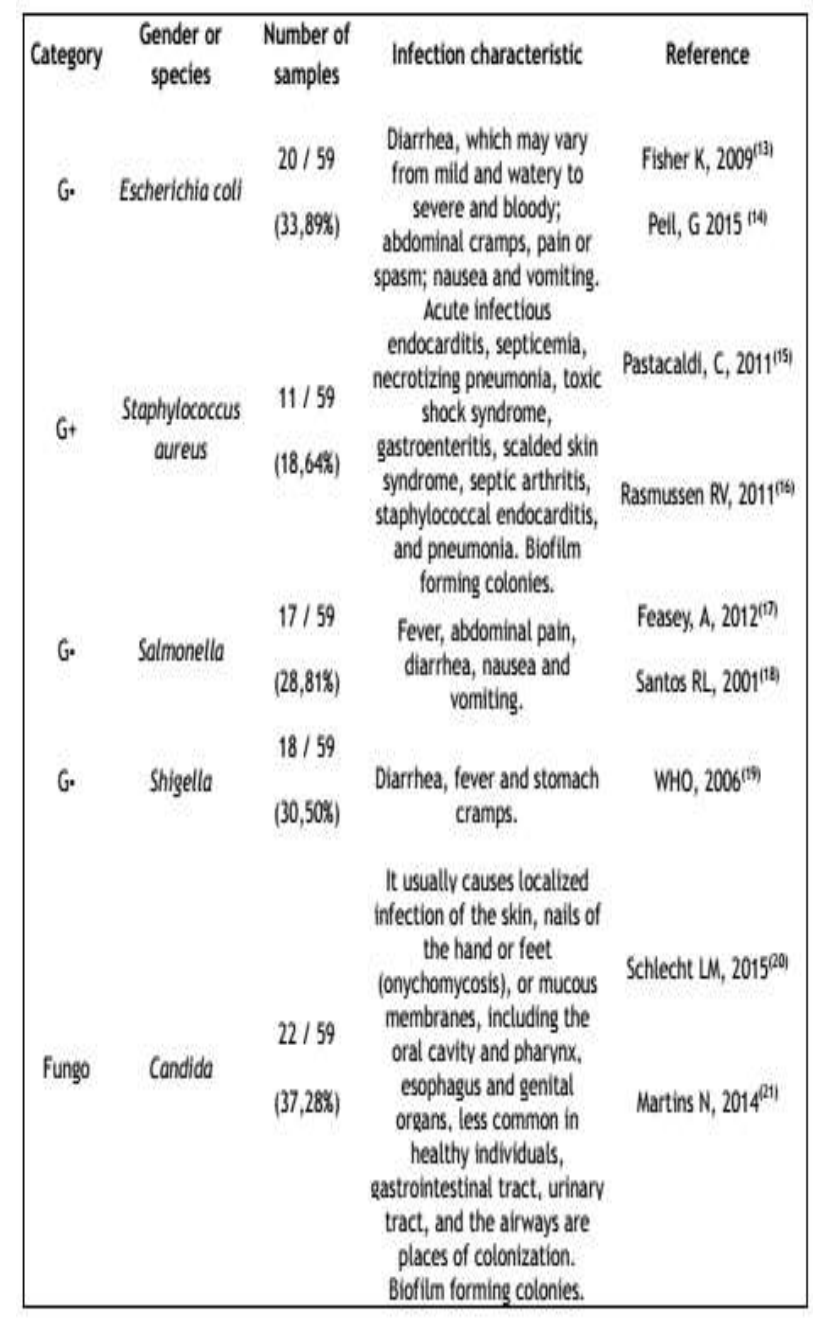

S. aureus is one of the main agents of infection in health services and its importance is also related to mechanisms of virulence and ability to resist the action of antimicrobials, besides the rapid dissemination among people and in diverse environments.

Patients colonized or infected with methicillin-resistant S. aureus (MRSA) are environmental dispersants ${ }^{22}$. Currently the species is one of the great risks to the public health, since it has become recurrent the appearance and lines resistant to the vancomycin, antibiotic considered like the last bactericidal line of defense administered in hospitals ${ }^{6}$.

Of the total number of cultured colonies, 11 colonies of S. aureus were found, through Manitol agar and coagulase and catalase tests. These samples were cultured and scattered on Müller Hinton agar and antibiotic paper discs were used to test the antimicrobial activity of these isolated colonies, as shown in Table 2.

Table 2 - Results of antimicrobial activity tests evaluated by disc-diffusion technique in agar.

\begin{tabular}{|c|c|c|c|c|c|}
\hline \multirow{2}{*}{$\begin{array}{l}\text { Strains S. } \\
\text { aureus }\end{array}$} & \multicolumn{5}{|c|}{ Degree of resistance to antibiotics } \\
\hline & $\begin{array}{c}\text { Nalidixic } \\
\text { Acid }\end{array}$ & $\begin{array}{c}\text { Amoxicillin + } \\
\text { Clandanic } \\
\text { Acid }\end{array}$ & Azithromycin & Oxacilin & Vancomycin \\
\hline CHS 1 & s & R & s & $R$ & s \\
\hline CHS 2 & R & R & s & R & R \\
\hline CHS 3 & s & 1 & s & R & R \\
\hline CAS 1 & s & 1 & R & R & R \\
\hline $\cos 2$ & s & R & R & R & R \\
\hline CAS 3 & s & s & s & R & R \\
\hline TC & s & $s$ & 1 & R & R \\
\hline CNS 1 & s & R & R & R & R \\
\hline $\operatorname{Cos} 2$ & s & s & s & $R$ & R \\
\hline CES & s & s & s & R & R \\
\hline LIBRARY & R & s & s & R & R \\
\hline ATCC & $s$ & $s$ & $s$ & $s$ & s \\
\hline
\end{tabular}

Note: I - intermediate phenotype; R - resistant phenotype; $\mathrm{S}$ - sensible phenotype. Center for Agricultural Sciences - CAS; Center of Educational Sciences - CES; Center for Human Sciences and Letters - CHSL, Center for Natural Sciences - CNS; Center for Health Sciences - CHS and Technology Center -TC.

In view of the first results in which almost all isolates of $S$. aureus presented resistance to vancomycin, it was necessary to test in a control sample (strain ATCC), because it was believed that the discs could be unviable for the antibiogram. However, it was observed that the ATCC strain was sensitive to 
all the antimicrobial discs tested (Table 2), proving that the strains of $S$. aureus used and coming from the fountain taps were approximately $91 \%$ resistant to Vancomycin and 9\% referring to the drinking fountain of the sample "CCS 1" did not present resistance to the antimicrobial. Oxacillin, a methicillin analog indicative of methicillin resistant $S$. aureus (MRSA) populations was also used in the experiments, and the results show a $100 \%$ resistance to this antimicrobial tested.

This is surprising given that it is an antimicrobial used only in hospitals and clinics. Studies in the USA have shown a higher prevalence of $S$. aureus and MRSA in the emergency department than in other sectors of a hospital, which makes their high pathogenicity even more dramatic ${ }^{22}$.

Previous studies have already indicated that Nursing students from a public university in Teresina were examined for the presence of S. aureus in their nasal cavity and an average of $40 \%$ of students infected with ORSA (Staphylococcus aureus Resistant to Oxacillin) and $42 \%$ with S. aureus with intermediate resistance to oxacillin ${ }^{10}$.

Therefore, finding isolated populations of $S$. aureus in the environment presenting as ORSA is of concern and suggests the need for a follow up of the quality of the cleaning performed in university drinking fountains. It should also be taken into account that many health students who study in Teresina hospitals attend these drinking fountains, serving as dispersing agents of these microorganisms, as well as dispersers in and out of hospitals.

\section{CONCLUSION}

Through the study it was possible to show the presence of different types of microorganisms in the internal part of the taps of the drinkers, due to the growth of biofilms on the internal surfaces of the apparatus that has contact with water, becoming a means of transmission of pathogens and increasing the risk of transmission of waterborne diseases. Isolated populations of $S$. aureus resistant to the antimicrobials tested, in particular vancomycin and oxacillin, are extremely dangerous to human health, since they are organisms often implicated in serious community and hospital infections.

It is therefore imperative that university management make provision for the monitoring and cleaning of appliances to occur more frequently in order to prevent the spread and development of water-borne diseases in the academic community.

\section{REFERENCES}

1.Marengo JA. Água e mudanças climáticas. Est. Avan. [Internet]. 2008 [cited 2017 Sep 07]; 22(63):83-96. Available from:. https://dx.doi.org/10.1590/S0103-

40142008000200006

2.Santos CC, Santos SDS, Freitas DRJ. Análise microbiológica de água de poço arterasanal de uma unidade municipal e sua relação com aprendizagem escolar em União/PI. [Trabalho de Conclusão de Curso]. Teresina: PARFOR; 2016.

3. Brasil. Ministério da Saúde. Portaria n. 2914, de 12 de dezembro de 2011. Dispõe sobre os procedimentos de controle e de vigilância da qualidade da água para consumo humano e seu padrão de potabilidade. Diário Oficial da União, Brasília, p. 39, 12 dez. 2011. Seção 1. 4. Okura MH, Siqueira KB. Enumeração de coliformes totais e coliformes termotolerantes em água de abastecimento e de minas. Ver de Hig Aliment [Internet]. 2005 Sep [cited 2017 Sep 07]; 19(135):86-91. Avaliable from: http://bases.bireme.br/cgi-

bin/wxislind.exe/iah/online/?lsisScript=iah/iah 
.xis\&src=google\&base $=$ LILACS\&lang=p\&nextActi on=lnk\&exprSearch=421565\&indexSearch=ID

5. Carvalho VFM. Análise da qualidade das águas do rio Parnaíba no meio urbano da cidade de Teresina-PI. XXIII Semin de Ini Cient VI Semin. em Desenvol. Tecnol. e Inov. [Internet]. 2014 [cited 2017 Sep 07]; ISSN 1518-7772 Avaliable from: http://sis.ufpi.br/23sic/?pagina=resumos_ic_ci enciaexatas

6. Tortora GJ, Funke BR, Case CL. Microbiologia. 10. ed., Porto Alegre: Artmed, 2012.

7. Xavier JB, Picioreanu C, Almeida JS, Van loosdrecht MCM. Monitorização e modelação da estrutura de biofilmes. Bol de Biotec [Internet]. 2003 [cited 2017 Sep 07]; 76(1):213.

8.Brasil. Ministério da Saúde. PORTARIA n. ${ }^{\circ}$ 518, de 25 de Março de 2004. Estabelece os procedimentos e responsabilidades relativos ao controle e vigilância da qualidade da água para consumo humano e seu padrão de potabilidade, e dá outras providências. Diário Oficial da República Federativa do Brasil, Brasília, DF, 2004.

9.Brasil. Fundação Nacional de Saúde. Manual técnico de análise de água. Brasília: Funasa, 2013.

10.Carvalho MSM, Andrade DFR de, Sousa AFL de, Valle ARM da C, Freitas DRJ, Nascimento GC et al. Nasal colonization with Staphylococcus aureus in nursing students: ground for monitoring. Rev Bras Enferm [Internet]. $2016 \quad$ Dec [cited 2017 Sep 07]; 69(6):1046-1051. Available from: http://dx.doi.org/10.1590/0034-71672016-0210.

11.Hartmann A, Missio R, Hammad MP, Alves IA. Incidência de Candida spp. na mucosa oral de pacientes infectados pelo vírus da imunodeficiência humana (HIV) no município de Santo Ângelo-RS. Rev de Epidem e Control de Infec [Internet]. 2016 Jul [cited 2017 Sep 07]; 6(3):125-130. Avaliable from: http://dx.doi.org/10.17058/reci.v6i3.6556

12. Moraes DMC. Investigação bacteriológica e molecular de Salmonella sp. em granjas de postura comercial. [Tese de Doutorado em Ciência Animal] Goiânia: Universidade Federal de Goiás; 2014.

13.Fisher K, Phillips C. The ecology, epidemiology and virulence of Enterococcus. Microbio [Internet]. 2009 Jun [cited 2017 Sep 07]; 155(6):1749-57. Avaliable from: doi:10.1099/mic.0.026385-0

14.Peil GHS, Kuss, AV, Gonçalves MCF. Avaliação da qualidade bacteriológica da água utilizada para abastecimento público no município de Pelotas - RS - Brasil. Ciênc. e Natura. [Internet]. 2015 [cited 2017 Sep 07]; 37(1):79-84. Avaliable from: DOI:10.5902/2179460X14941

15.Pastacaldi, C, Lewis P, Howarth P. Staphylococci and staphylococcal superantigens in asthma and rhinitis: a systematic review and meta-analysis. Allergy [Internet]. 2011 [cited 2017 Sep 07]; 66(4):549555. Avaliable from: doi:10.1111/j.13989995.2010.02502.x.

16. Rasmussen RV, Fowler VG; Skov R, Bruun NE. Future challenges and treatment of Staphylococcus aureus bacteremia with emphasis on MRSA. Futur Microbiol [Internet]. 2011 Jan [cited 2017 Sep 07]; 6(1):43-56. Avaliable from: doi:10.2217/fmb.10.155.

17.Feasey NA, Dougan G, Kingsley RA, Heyderman RS, Gordon MA. Invasive nontyphoidal Salmonella disease: an emerging and neglected tropical disease in Africa. The Lancet. [Internet]. 2012 [cited 2017 Sep 07]; 379:2489-99. Avaliable from: doi:10.1016/s0140-6736(11)61752-2.

18.Santos RL, Shuping Z, Renee MT, Robert AK, L. Gary Adams; Adreas JB. Animal models od Salmonella infections: enteritis versus typhoid 
fever. Microbes and Infec [Internet]. 2001 [cited 2017 Sep 07]; 3:1335-1344. Avaliable from: doi:10.1016/s1286-4579(01)01495-2.

19.World Health Organization. Shigellosis. State of the art of new vaccine research and development. Immunization, Vaccines and Biologicals. 2006. pp. 10-2

20.Schlecht LM, Freiberg JA, Hänsch GM, Peters BM, Shirtliff ME, Krom BP, et al. Systemic Staphylococcus aureus infection mediated by Candida albicans hyphal invasion of mucosal tissue. Microbiol. [Internet]. 2015 [cited 2017 Sep 07]; 161(1):168-81. Avaliable from: doi: 10.1099/mic.0.083485-0.
21. Martins N, Ferreira IC, Barros L, Silva S, Henriques M. Candidiasis: predisposing factors, prevention, diagnosis and alternative treatment. Mycopathol. [Internet]. 2014 Jun [cited 2017 Sep 07]; 177(5-6):23-240. Avaliable from: doi:10.1007/ s11046-014-9749-1.

22. Suffoletto BP, Cannon ETH, Ilkhanipour K, Yealy DM. Prevalence of Nasal Colonization in Emergency Department Personnel. Annals of Emergen Med. [Internet] .2008 [cited 2017 Sep 07]; 52(5)529-533. Avaliable from: http://dx.doi.org/10.1016/j.annemergmed.20 08.03.020.

\section{COLABORAÇÕES}

Moreira AM, Aguiar WJL, Dias ODS, Silva TM, Cardoso AOS e Santos LB contribuíram com a coleta do material, análise e interpretação dos resultados, redação, revisão crítica do conteúdo e aprovação da versão final. Freitas DRJ contribui na análise e interpretação dos resultados, redação, revisão crítica do conteúdo, analisando e aprovando a versão final.

\section{CONFLITOS DE INTERESSE}

Não há conflitos de interesse a declarar

\section{CORRESPONDÊNCIA}

Daniela Reis Joaquim de Freitas

Universidade Federal do Piauí

Programa de Pós-Graduação em Ciências da Saúde.

Campus Universitário Ministro Petrônio Portella - Bairro Ininga - Teresina - PI

E-mail:drjfreitas@ufpi.edu.br 